J. Dairy Sci. 91:4579-4591

doi:10.3168/jds.2008-1215

(c) American Dairy Science Association, 2008.

\title{
Precipitation and Temperature Effects on Mortality and Lactation Parameters of Dairy Cattle in California
}

\author{
C. L. Stull, ${ }^{\star 1}$ L. L. McV. Messam,† C. A. Collar,‡ N. G. Peterson,§ A. R. Castillo,\# B. A. Reed,„ \\ K. L. Andersen, $\uparrow$ and W. R. VerBoort ${ }^{\star \star}$ \\ *Veterinary Medicine Cooperative Extension, University of California, Davis 95616 \\ †School of Veterinary Medicine, University of California, Davis 95616 \\ ¥Kings County Cooperative Extension, Hanford, CA 93230 \\ §San Bernardino County Cooperative Extension, San Bernardino, CA 92415 \\ \#Merced County Cooperative Extension, Merced, CA 95341 \\ ||Architecture Department, University of Oregon, Eugene 97403 \\ 『Humboldt County Cooperative Extension, Eureka, CA 95503 \\ ${ }^{* *}$ AgriTech Analytics, Visalia, CA 93291
}

\section{ABSTRACT}

Data from 3 commercial rendering companies located in different regions of California were analyzed from September 2003 through August 2005 to examine the relationship of dairy calf and cow mortality to monthly average daily temperature and total monthly precipitation respectively. Yearly average mortality varied between rendering regions from 2.1 to $8.1 \%$ for mature cows. The relationship between cow and calf monthly mortality and monthly average daily temperature was U-shaped. Overall, months with average daily temperatures less than 14 and greater than $24^{\circ} \mathrm{C}$ showed substantial increases in both calf and cow mortality with calf mortality being more sensitive to changes in these temperature ranges than cow mortality. Temperature changes were reflected in a 2 -fold difference between the minimum and maximum mortality in cows and calves. Precipitation showed a weak effect with calf mortality and no effect with cow mortality. Data from Dairy Herd Improvement Association were used from 112 California herds tested over a 24-mo period to examine the relationship of milk production and quality with monthly average daily temperature and monthly precipitation. Somatic cell count and percent milk fat were either weakly or not associated with monthly average daily temperature and total monthly precipitation. However, total monthly precipitation was negatively associated with test day milk per milking cow regardless of the dairy's geographical location. Housing-specific associations for test day milk per milking cow were greater for total monthly precipitation than monthly average daily temperature, with the strongest negative asso-

Received March 31, 2008.

Accepted July 21, 2008.

${ }^{1}$ Corresponding author: clstull@ucdavis.edu ciation seen for dairies that do not provide shelter for cows. This suggests that providing suitable housing for lactating dairy cattle may ameliorate the precipitationassociated decrease in test day milk per milking cow.

Key words: dairy cow, mortality, milk yield, precipitation and temperature

\section{INTRODUCTION}

The welfare of dairy cattle may be affected by extreme weather events such as excessive rainfall in the winter and heat stress during the summer. Much of the state of California has a Mediterranean climate with rainy winters and hot, dry summers. Annual losses of $\$ 5$ to $\$ 6$ billion are attributed to heat stress in dairy cows in the United States (Ray et al., 1992), with an estimated \$118-million loss in California during 2000 (St-Pierre et al., 2003). Numerous studies have examined the physiology, production, genetics, and management tools of heat stress, under both climatic laboratory and on-farm conditions. The negative effects of heat stress in dairy cattle are well documented (Armstrong et al., 1999; West, 2003; Berman, 2005). Lactating cows suffering from heat stress seek and remain in the shade, reduce feed intake, and show an immediate drop in daily milk yield. Conception rate suffers, and subsequent calving interval is lengthened. Mortality is greater, especially among cows that have recently calved with dystocia or mastitis. Management strategies for mitigating heat stress include provision of shade, sprinklers, and fans. In the Central Valley of California, where summers are long, hot, and dry, lactating cattle are housed in dry lot corrals with shades or free stall barns. Most dairies also utilize manger or feed bunk sprinkler systems (with or without fans) to provide additional cooling where the animals stand to eat. These systems have been shown to decrease losses in milk yield, decrease mortality in 
postparturient cows, improve reproductive parameters (services/conception, conception rate, days open), and improve appetite (Shultz and Morrison, 1987). Although cooling of dry cows is less common, a recent study has shown that preparturient cows in California also benefit from cooling. Cooling preparturient dairy cows with shades, fans, and sprinklers compared with sprinklers alone improved total $60-\mathrm{d}$ milk production by $84.3 \mathrm{~kg} /$ cow, and increased profitability by $\$ 2,131$ per cow (Urdaz et al., 2006). There is a dearth of scientific information on the specific effects of rainfall (Fox and Tylutki, 1998). However, excessive moisture in the ground or bedding of dairy cattle has various effects on their behavior and physiology. Rainy or wet conditions have been shown to drastically reduce the time dairy cattle spend lying down (Tucker et al., 2007). Also in beef cattle, there is a much greater level of energy expenditure when walking in muddy and wet conditions (Dijkman and Lawrence, 1997), along with a reduction in feed intake (Fox and Tylutki, 1998). The lack of cleanliness associated with wet environments affects various health conditions in dairy cattle including an increase in uterine and intramammary environmental pathogens (Schreiner and Ruegg, 2003) that predispose dairy cattle to endometritis (Lewis, 1997; Heuwieser et al., 2000) and mastitis, respectively, the latter leading to milk contamination (Anderson and Walker, 1988). Lameness is one of the most costly diseases on dairy farms (Kossaibati and Esslemont, 1997), and wet conditions contribute to softer hooves and an increase in lameness (Borderas et al., 2004; van Amstel et al., 2004). Other diseases of the skin associated with wet weather include ringworm and bovine dermatophilosis (Loeffler et al., 2004). Anecdotal reports also have described how excessive rainfall resulted in muddy living conditions; lame or sick cows, or both; decreased milk production; and increased mortality in cattle (Davis et al., 1997; Kirk, 1997). Furthermore, during the heavy rainfall in Southern California in early 2005, there was a noticeable increase in the number of carcasses picked up from dairies by rendering companies, with some companies having to accumulate the carcasses before processing due to limited capacity of the facility (personal communication, anonymous).

This ecological study examined the effects of seasonal weather events (winter rain and summer heat) on mortality, milk production, and milk quality on dairies located throughout California using data from rendering facilities and Dairy Herd Improvement Association from September 2003 through August 2005. The working hypothesis is that winter precipitation and summer heat affect group level mortality, milk quality, and milk production on California dairies. The study had 3 major objectives: 1) to examine the relationship of precipita- tion and environmental temperature to bovine mortality, milk quality, and milk production on California dairies; 2) to determine if a threshold of precipitation and temperature exists that affects mortality on California dairies; and 3) to extend the results to provide a basis for further weather-related investigation that will assist rendering companies in predicting fluctuations in carcass supply and support dairy management in enhancing welfare of dairy cows and calves.

\section{MATERIALS AND METHODS}

\section{Mortality Data}

Three commercial rendering companies located in California agreed to provide data on the number of dairy cattle (mature cows and calves) processed monthly from September 1, 2003, to August 31, 2005. All of the rendering companies serviced 3 or 4 counties with no overlap between counties served. The company designated as Sacramento serviced Solano, Yolo, Sacramento, and San Joaquin counties, the company designated as Hanford serviced Kings, Madera, Tulare, and Fresno counties, and the company designated as Merced serviced Stanislaus, Merced, and Kern counties. Both Sacramento and Hanford rendering companies provided 24 mo of data, and the Merced company provided data for 20 mo (January 2004 to August 2005). Weather stations were selected from the California Weather Database for each rendering company, and data were obtained for monthly average daily temperature and total monthly precipitation. The local weather stations located in Hanford, Merced, and Sacramento were selected to represent the regions serviced by the rendering companies.

\section{Lactation Data}

A total of 121 commercial dairies located throughout California agreed to participate in the study. The dairies were categorized onto 4 geographical locations using California Department of Food and Agriculture Marketing Branch regions, which included North Coast, North Valley, South Valley, and Southern California. Data on milk parameters [test day milk produced per milking cow (kg), milk fat (\%), and SCC (cells/mL)] were obtained from DHIA records for each dairy. Each dairy was tested once per month during the period of September 1, 2003, to August 31, 2005. The type of housing utilized on each dairy (freestall, loafing barn, corral, pasture, or combination of housing types) was requested from each cooperating dairy and added to the data set. The housing types were assigned to 3 categories: inside confinement type housing with shelter consisting of free stalls and loafing barns, outside housing 
without shelter including corrals and pastures, and the combination of inside confinement and outside housing types. Weather stations in close proximity to each of the dairies were selected and data were obtained from the California Weather Database as described previously.

\section{Statistical Analyses}

Bovine Mortality. The absolute number of cow and calf deaths for the Hanford, Merced, and Sacramento rendering companies were modeled using a Poisson regression model with average monthly temperature and total monthly precipitation used separately as exposures of interest. The Poisson model employed was $\ln (\mu)=\beta X$ (Agresti, 1996), where $\ln (\mu)=$ the natural logarithm of the mean total number of deaths and $\beta X$ $=\mathrm{a}$ linear combination of the predictor variables and regression coefficients. When monthly average daily temperature was used as the exposure of interest, no other predictor was included in the model. Because it was reasoned that temperature independently predicted both precipitation levels and bovine mortality, when total monthly precipitation was used as the exposure of interest, monthly average daily temperature was included in the model as a confounding variable. Both monthly average daily temperature and total precipitation were modeled as both continuous and categorical variables. When modeled as continuous variables, their functional forms were determined by the method of fractional polynomials (Royston et al., 1999). Each model was checked for overdispersion and routinely accounted for by adjusting the scale parameter (Allison, 1999). The data were analyzed in SAS version 9.1 (SAS Institute Inc., Cary, NC).

Lactation Data. The final data set was created in Microsoft Excel (Microsoft, Redmond, WA) and consisted of lactation data for 112 dairies located in the geographical locations of the North Coast $(n=25)$,
North Valley $(\mathrm{n}=34)$, South Valley $(\mathrm{n}=35)$, and Southern California $(\mathrm{n}=18)$. Average daily temperatures for each month and total monthly precipitation were linked to each dairy by using the month of testing. Missing test day values were imputed longitudinally by linear interpolation (Twisk and de Vente, 2002). No more than 2 successive missing test day values were interpolated, and dairies with missing values for more than $50 \%$ of test days during the study period were excluded from analysis. The data were analyzed using a generalized estimating equations approach to linear regression with an exchangeable correlation structure in SAS version 9.1 (Twisk, 2003). The separate effects of monthly average daily temperature and total monthly precipitation on somatic cell count, test day milk per milking per cow, and percentage of milk fat were investigated. For the effects of precipitation and temperature on test day milk per milking cow, 2 types of stratified analyses were performed with the strata being determined by geographic location and housing type.

\section{RESULTS}

\section{Weather Data for Rendering Regions}

The distribution of monthly average daily temperatures did not differ dramatically between rendering regions with median monthly average daily temperature ranging from 16.6 to $17.7^{\circ} \mathrm{C}$ and interquartile ranges being very similar (Table 1). Over the study period, Sacramento $\left(16.6^{\circ} \mathrm{C}\right)$ experienced slightly lower monthly average daily temperatures compared with Hanford and Merced (17.7 and $17.4^{\circ} \mathrm{C}$, respectively). Both Merced and Sacramento experienced substantially more rainfall than Hanford over the study period with half of the months having at least $1.9 \mathrm{~cm}$ of rainfall compared with $1 \mathrm{~cm}$. In addition, the rainiest $25 \%$ of months in the Hanford region had precipitation of 5.1 to $6.7 \mathrm{~cm}$, whereas Merced and Sacramento had 6.2

Table 1. Summary statistics for monthly average daily temperature $\left({ }^{\circ} \mathrm{C}\right)$ and total monthly precipitation $(\mathrm{cm})$ for the Hanford, Merced, and Sacramento (Sac) rendering regions

\begin{tabular}{lccccccc}
\hline & \multicolumn{3}{c}{ Temperature $\left({ }^{\circ} \mathrm{C}\right)$} & & \multicolumn{3}{c}{ Precipitation $(\mathrm{cm})$} \\
\cline { 2 - 3 } \cline { 7 - 8 } Variable & Hanford & Merced & Sac & & Hanford & Merced & Sac \\
\hline Months, $\mathrm{n}$ & 24 & 20 & 24 & & 24 & 20 & 24 \\
Mean & 17.4 & 17.7 & 16.6 & & 2.1 & 3.4 & 3.8 \\
Median & 17.4 & 17.5 & 16.9 & & 1.0 & 1.9 & 1.9 \\
Mode & 20.3 & $\mathrm{NA}^{1}$ & NA & & 0.0 & 0.0 & 0.0 \\
Minimum & 6.5 & 7.7 & 7.6 & & 0.0 & 0.0 & 0.0 \\
Maximum & 28.6 & 28.4 & 26.0 & & 6.7 & 12.9 & 12.7 \\
Percentile & 10.3 & 11.7 & 10.7 & & 0.0 & 0.02 & 0.08 \\
25 & 23.4 & 23.1 & 22.3 & & 5.1 & 6.2 & 6.8 \\
75 & & & & & & & \\
\hline
\end{tabular}

${ }^{1} \mathrm{NA}=$ not available. 
to $12.9 \mathrm{~cm}$ and 6.8 to $12.7 \mathrm{~cm}$, respectively. Merced and Sacramento also experienced greater variation in precipitation than Hanford with interquartile ranges $\geq$ $6.2 \mathrm{~cm}$ compared with Hanford (interquartile range $=$ $4.1 \mathrm{~cm}$ ). There was no rainfall in 10, 6 , and 6 mo during the study period for Hanford, Sacramento, and Merced rendering regions, respectively.

\section{Bovine Mortality}

Descriptive statistics for the number of cow and calf deaths of each rendering region are presented in Table 2. The number of dairy cattle located in the Hanford, Merced, and Sacramento regions for 2004 was 765,020, 537,421 , and 127,494 , respectively (CDFA, 2005). Thus, using the mean monthly mortality during 2004 for each region, the annual mortality based on carcasses collected by each of the rendering companies of Hanford, Merced, and Sacramento was approximately 8.1, 5.6, and $2.1 \%$, with an overall mortality rate for mature cows of $6.6 \%$. The greatest number of dead cows and calves were collected in the Hanford region, with calves greatly outnumbering cows (Table 1 ). The ratio of the month with maximum mortality to the month with minimum mortality for cows and calves, respectively, is 2.5 and 2.1 for the Hanford region, 2.1 and 2.5 for the Merced region, and 1.8 and 1.9 for the Sacramento region.

Temperature. Summary statistics of monthly average daily temperature for the Hanford, Merced, and Sacramento rendering regions are provided in Table 1. Temperature and bovine mortality showed a U-shaped relationship (Figure 1) with an increase in deaths at both the low and high extremes of temperature. This U-shaped relationship was true for both calves and cows and consistent across rendering regions. Within any one rendering region, changes in calf mortality were larger than changes in cow mortality for commensurate changes in temperatures at the extremes of the temperature range (Table 3). For instance in Merced at $8^{\circ} \mathrm{C}$, a $2^{\circ} \mathrm{C}$ increase in temperature would be associated with a $16.4 \%$ decrease in mortality in calves compared with a $9.2 \%$ decrease in mortality for cows. Similarly a $2^{\circ} \mathrm{C}$ increase in temperature at $26^{\circ} \mathrm{C}$ would result in a 10.7 and $9.7 \%$ increase in mortality for calves and cows, respectively. This pattern was consistent regardless of geographical region. Over all 3 rendering regions, $2^{\circ} \mathrm{C}$ increases in temperature between 14 and $20^{\circ} \mathrm{C}$ did not result in changes in mortality greater than $10 \%$, and changes in mortality between 16 and $18^{\circ} \mathrm{C}$ were less than $6 \%$. Poisson regression models expressing the relationship between temperature and bovine mortality are provided in Table 4.

Precipitation. Summary statistics of monthly accumulated precipitation for the Hanford, Merced, and Sacramento rendering regions are provided in Table 1. When precipitation was modeled as a continuous variable using fractional polynomials, the results did not suggest any difference in the effects of precipitation at different levels of rainfall. Consequently, for final analyses, precipitation was modeled as a categorical variable with 2 levels $(0$ and $>0)$, and only those results are presented. After controlling for the potential confounding effects of temperature, only for calves in the Hanford region did the effect of precipitation approach statistical significance with a decrease $(16.9 \%)$ in mortality in months with rainfall compared with months without rain $[95 \%$ confidence interval $(\mathbf{C I}):-31.9 \%$ to $1.2 \%$; $P=0.07$; Table 5]. The effect of precipitation on cows in Hanford as well as cows and calves in Merced and Sacramento was not significant $(P>0.60)$, although the overall trend was a decrease in mortality in months with rainfall compared with months without rainfall. Poisson regression models expressing the relationship between precipitation and bovine mortality are provided in Table 4.

\section{Lactation Parameters}

Location Description. Over the study period, herds in Southern California tended to experience higher minimum monthly average daily temperatures,

Table 2. Summary statistics for cow and calf monthly mortality (\# of head) the Hanford, Merced, and Sacramento (Sac) rendering regions

\begin{tabular}{lrrrrrrr}
\hline & \multicolumn{3}{c}{ Cows } & & \multicolumn{3}{c}{ Calves } \\
\cline { 2 - 3 } \cline { 6 - 8 } Variable & Hanford & Merced & Sac & & Hanford & Merced & Sac \\
\hline Months, $\mathrm{n}$ & 24 & 20 & 24 & & 24 & 21 & 24 \\
Mean & 5,382 & 2,638 & 237 & & 14,197 & 2,287 & 455 \\
Median & 5,249 & 2,640 & 229 & & 14,222 & 2,105 & 455 \\
Minimum & 3,199 & 1,817 & 172 & & 8,957 & 1,309 & 339 \\
Maximum & 7,973 & 3,784 & 305 & & 18,872 & 3,324 & 645 \\
Percentile & & & & & & & \\
25 & 4,647 & 2,344 & 216 & & 12,581 & 1,854 & 405 \\
75 & 6,347 & 2,882 & 259 & & 15,997 & 2,890 & 489 \\
\hline
\end{tabular}


whereas herds in the North Coast tended to experience lower maximum monthly average daily temperatures than herds in the other locations (Figure 2a). Fluctuations of monthly average daily temperature for the North and South Valley were essentially the same. North Coast, North Valley, South Valley, and Southern California experienced (in that order) decreasing levels of precipitation over the study period (Figure 2b). Both mean and variability in herd sizes of the dairies varied between geographic locations, with the North Coast $(370 \pm 194)$ and South Valley $(1,560 \pm 1,107)$ having the smallest and largest herd means and standard deviations, respectively. However, the mean $365 \mathrm{~d}$ rolling herd average, test day milk per milking cow, SCC, and percentage fat were similar for herds from the different geographic locations (Table 6). (a) Merced - Calves

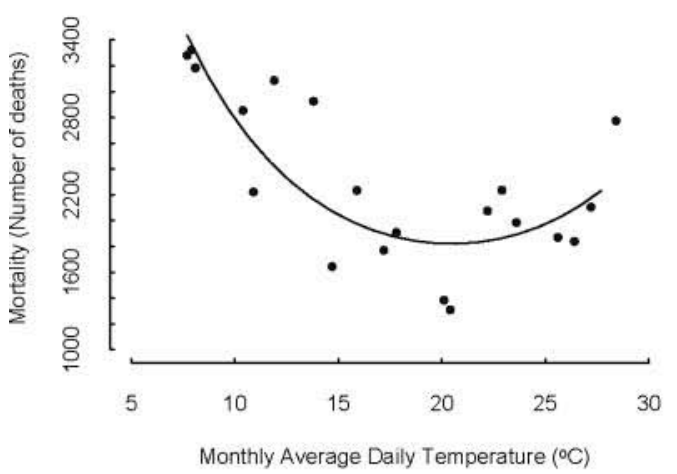

(c) Hanford - Calves

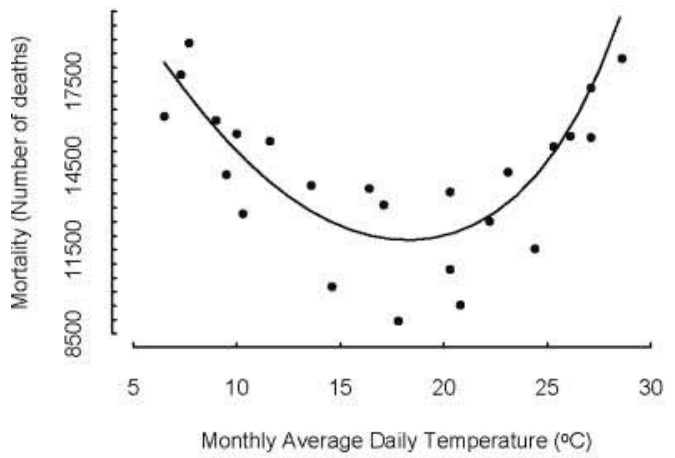

(e) Sacramento - Calves

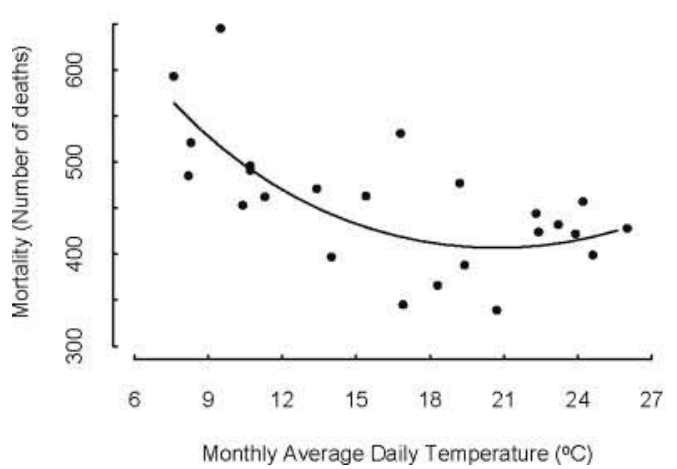

(b) Merced - Cows

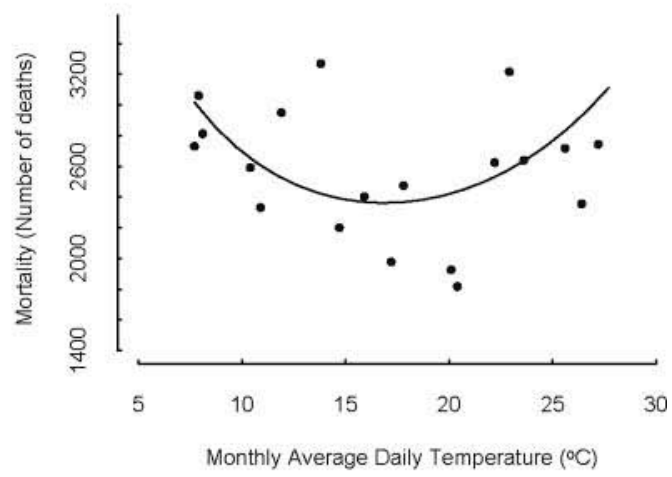

(d) Hanford - Cows

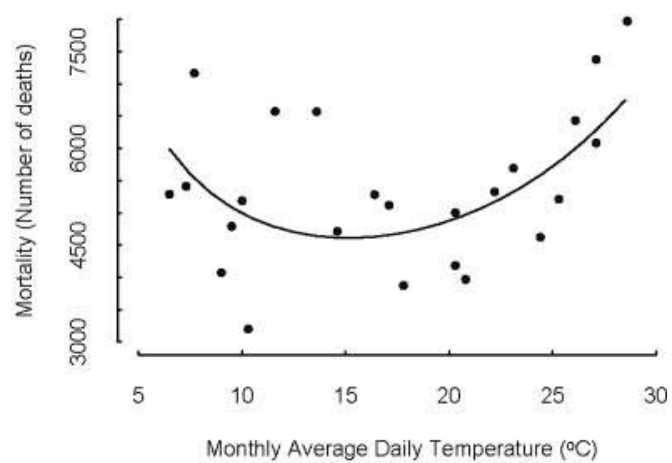

(f) Sacramento - Cows

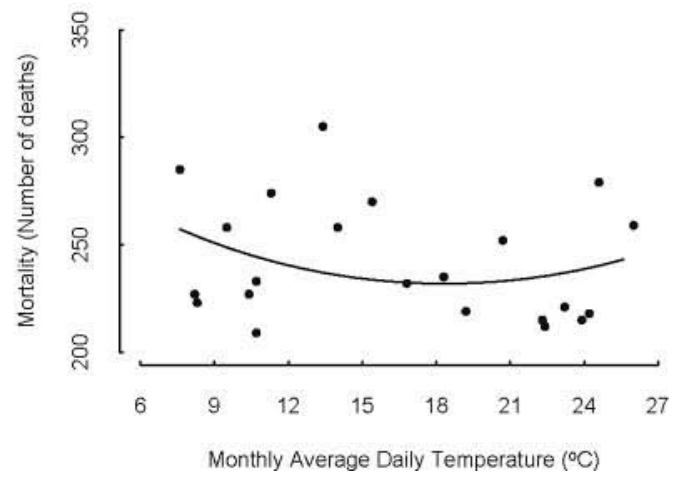

Figure 1. The effect of monthly average daily temperature $\left({ }^{\circ} \mathrm{C}\right)$ on mortality (number of deaths) for calves and cows in the Merced, Hanford, and Sacramento rendering regions. 
Table 3. Poisson regression results for percentage change in average monthly bovine mortality for $2^{\circ} \mathrm{C}$ increases in monthly average daily temperature $\left({ }^{\circ} \mathrm{C}\right.$ ) calculated at different monthly average daily temperatures during 24 mo (September 2003 to August 2005)

\begin{tabular}{|c|c|c|c|c|c|c|c|}
\hline \multirow[b]{2}{*}{ Region } & \multirow{2}{*}{$\begin{array}{c}\text { Monthly } \\
\text { average daily } \\
\text { temperature } \\
\left({ }^{\circ} \mathrm{C}\right)\end{array}$} & \multicolumn{3}{|c|}{ Calves } & \multicolumn{3}{|c|}{ Cows } \\
\hline & & $\begin{array}{c}\text { Mortality } \\
\text { change }(\%)\end{array}$ & Upper & Lower & $\begin{array}{l}\text { Mortality } \\
\text { change (\%) }\end{array}$ & Upper & Lower \\
\hline \multirow[t]{8}{*}{ Merced $^{1}$} & 8 & -16.4 & -21.8 & -10.5 & -9.2 & -15.7 & -2.1 \\
\hline & 10 & -13.7 & -31.0 & 7.9 & -6.5 & -20.2 & 9.5 \\
\hline & 12 & -11.0 & -29.9 & 13.1 & -4.2 & -18.2 & 12.3 \\
\hline & 18 & -2.3 & -26.6 & 30.2 & 2.1 & -13.9 & 21.1 \\
\hline & 20 & 0.8 & -25.4 & 36.4 & 4.1 & -12.7 & 24.1 \\
\hline & 22 & 4.0 & -24.3 & 42.9 & 6.0 & -11.6 & 27.1 \\
\hline & 24 & 7.3 & -23.1 & 49.8 & 7.9 & -10.6 & 30.2 \\
\hline & 26 & 10.7 & -21.9 & 57.0 & 9.7 & -9.7 & 33.3 \\
\hline \multirow[t]{5}{*}{ Hanford } & 8 & -10.1 & -12.5 & -7.6 & -8.3 & -15.5 & -0.4 \\
\hline & 20 & 5.1 & -48.7 & 115.2 & 5.4 & -7.2 & 19.6 \\
\hline & 22 & 9.3 & -50.6 & 142.2 & 7.0 & -6.1 & 21.9 \\
\hline & 24 & 14.1 & -52.4 & 173.6 & 8.6 & -5.1 & 24.3 \\
\hline & 26 & 19.4 & -54.0 & 210.1 & 10.1 & -4.3 & 26.6 \\
\hline \multirow[t]{8}{*}{ Sacramento } & 8 & -8.5 & -13.4 & -3.3 & -3.3 & -9.1 & 2.8 \\
\hline & 10 & -7.1 & -11.0 & -3.1 & -2.6 & -6.8 & 1.8 \\
\hline & 12 & -5.7 & -23.3 & 15.9 & -1.9 & -22.7 & 24.4 \\
\hline & 14 & -4.2 & -23.2 & 19.4 & -1.2 & -23.3 & 27.3 \\
\hline & 16 & -2.8 & -23.1 & 22.9 & -0.5 & -24.0 & 30.3 \\
\hline & 18 & -1.3 & -23.0 & 26.5 & 0.2 & -24.6 & 33.3 \\
\hline & 20 & 0.2 & -22.9 & 30.3 & 1.0 & -25.3 & 36.4 \\
\hline & 22 & 1.8 & -22.8 & 34.2 & 1.7 & -25.9 & 39.6 \\
\hline
\end{tabular}

${ }^{1} 20 \mathrm{mo}$.

Temperature. During the 24-mo period, mean test day milk $(\mathrm{kg})$ per milking cow (mean change $=-0.018$, $95 \%$ CI: -0.036 to 0.001 ) and mean percentage milk fat (mean change $=-0.010,95 \% \mathrm{CI}:-0.011$ to -0.008 ) decreased for the 112 herds with a $1^{\circ} \mathrm{C}$ increase in monthly average daily temperature. Changes in SCC were insubstantial (mean change $=-652$ cells $/ \mathrm{mL}$ ) for the same comparison (Table 7). When the dairies were stratified according to housing type, only those dairies with cows kept in a combination of inside confinement (freestall, loafing barn) and outside facilities (corral or pasture) showed a reduction $(P=0.02)$ in mean test day milk per milking cow. This reduction was small (mean $=-0.035,95 \%$ CI: -0.063 to -0.006 ; Table 8). When the analysis was performed stratifying on geographical location, temperature was positively associated with milk production on the North Coast $(0.07 \mathrm{~kg} / \mathrm{d})$ but negatively associated with production in the other regions (Table 9). In particular the effect in the South Valley (mean change $=-0.04,95 \%$ CI:
-0.07 to -0.016$)$ was significant $(P=0.002)$. The effect of temperature on milk production in North Valley and Southern California dairies was almost identical. Though more consistent with a reduction in milk production, this was also consistent with no effect $(95 \%$ CI: -0.05 to 0.01 and -0.05 to 0.02 , respectively).

Precipitation. Over the study period, the mean test day milk per milking cow decreased $(-0.06 \mathrm{~kg})$, whereas percentage fat showed an increase $(0.004 \%)$ for a $1-\mathrm{cm}$ increase in total monthly precipitation over the study period. The change in mean SCC was also insubstantial (120 cells $/ \mathrm{mL}$ ) for the same comparison (Table 10). Stratification by housing type showed that this decrease in mean test day milk production ranged from 0.04 to $0.08 \mathrm{~kg}$ with the greatest effect of monthly precipitation seen in dairies that did not provide shelter for the cattle (pastures, corrals) (Table 11). When the analysis was performed stratifying on geographical location, total monthly precipitation showed a consistently negative association with milk production regardless of 
Table 4. Poisson regression models for mean monthly calf and cow mortality $(\bar{M})$ as a function of temperature $(\mathrm{T})$ and precipitation (PPT) for the Merced, Hanford, and Sacramento rendering regions

\begin{tabular}{llcc}
\hline & & \multicolumn{2}{c}{ Models (SE of regression coefficients in parentheses) } \\
\cline { 3 - 4 } Region & Animal & Temperature $(\mathrm{T})$ & Precipitation $^{1}\left(\mathrm{PPT}^{2}\right)$ \\
\hline Merced & Calf & $\ln (\bar{M})=9.14-0.16(0.04) T+0.0039(0.001) T^{2}$ & $\ln (\bar{M})=8.57-0.03(0.11) P P T-0.09(0.03) T+0.003(0.001) T^{2}$ \\
& Cow & $\ln (\bar{M})=9.22-0.47(0.18) \sqrt{T}+0.002(0.0006) T^{2}$ & $\ln (\bar{M})=9.22-0.03(0.11) P P T-0.46(0.19) \sqrt{T}+0.002(0.0007) T^{2}$ \\
Hanford & Calf & $\ln (\bar{M})=10.08-0.01(0.002) T^{2}+0.0042(0.0006) T^{2} \ln T$ & $\ln (\bar{M})=10.08-0.19(0.10) P P T-0.01(0.002) T^{2}+0.004(0.0006) T^{2} \ln T$ \\
& Cow & $\ln (\bar{M})=9.76-0.60(0.26) \ln T+0.0013(0.0005) T^{2}$ & $\ln (\bar{M})=9.82+0.08(0.17) P P T-0.63(0.27) \ln T+0.001(0.0006) T^{2}$ \\
Sacramento & Calf & $\ln (\bar{M})=6.82-0.08(0.03) T+0.002(0.0009) T^{2}$ & $\ln (\bar{M})=6.76-0.05(0.13) P P T-0.07(0.04) T+0.001(0.001) T^{2}$ \\
& Cow & $\ln (\bar{M})=5.75-0.03(0.03) T+0.0009(0.001) T^{2}$ & $\ln (\bar{M})=5.71+0.04(0.15) P P T-0.03(0.05) T+0.006(0.002) T^{2}$ \\
\hline
\end{tabular}

${ }^{1}$ Models with precipitation as predictor are adjusted for the potentially confounding effects of temperature. PPT $=1$ when precipitation $>0$ and 0 otherwise. $\beta_{\mathrm{i}}=$ ith parameter in regression model (numbered from left to right), cov $\left(\beta_{\mathrm{i}}, \beta_{\mathrm{j}}\right)=$ covariance of the ith and jth parameters. Temperature-Merced (Calf): cov $\left(\beta_{2}, \beta_{3}\right)=-0.000035$, Temperature-Merced (Cow): cov $\left(\beta_{2}, \beta_{3}\right)=-0.000108$ Temperature-Hanford (Calf): cov $\left(\beta_{2}, \beta_{3}\right)=-1.401 \times 10^{-6}$, Temperature-Hanford $(\mathrm{Cow}): \operatorname{cov}\left(\beta_{2}, \beta_{3}\right)=-0.000114$ Temperature-Sacramento $($ Calf $):$ cov $\left(\beta_{2}, \beta_{3}\right)=-0.000026$, Temperature-Sacramento (Cow): $\operatorname{cov}\left(\beta_{2}, \beta_{3}\right)=-0.000035$.

location with strongest effects seen in the North Coast and South Valley (Table 12). The association for the North Valley though negative $(-0.004)$ was also consistent with no association (95\% CI: -0.03 to 0.02 ; Table 12).

\section{DISCUSSION}

The upper critical temperature range for high producing dairy cows and calves has been identified as between 25 and $26^{\circ} \mathrm{C}$ (Berman et al., 1985; Webster, 1994) and is met when the animal can no longer dissipate enough metabolic heat to maintain homeothermy. When this occurs, vasodilation, sweating, and panting mechanisms are invoked to dissipate body heat (Curtis, 1983). At this time, feed intake during heat stress is also voluntarily reduced (Armstrong, 1994; West, 2003) resulting in less heat generated by digestion and absorption of nutrients. Additionally due to the U-shaped relationship of the nutrient energy requirement for maintenance and temperature in lactating cows, there is an increase in the energy requirement of maintenance with the temperature rising above (and below) 18 to $20^{\circ} \mathrm{C}$ (National Research Council, 1981). Thus, as the temperature rises, the energy requirement needs for maintenance increases, whereas feed intake is suppressed. Death can occur when the body temperature is $3^{\circ} \mathrm{C}$ higher than normal, but depends on the duration of heat stress, acclimation, BW, and production level among other factors (Curtis, 1983). The proportionately larger increases in mortality observed for both cows and calves in all 3 rendering regions when monthly average daily temperatures were above $24^{\circ} \mathrm{C}$ as compared with between 16 and $24^{\circ} \mathrm{C}$ (Table 3, Figure 1) is consistent with these previously published upper critical temperatures. Developing and implementing effective heat stress mitigation practices or cooling methods for dairy cattle may alleviate some of the mortality loss on

Table 5. Poisson regression results for percent change in average monthly bovine mortality in Merced, Hanford, and Sacramento rendering regions for months with precipitation (PPT, cm) compared with months without precipitation during 24 mo (September 2003 to August 2005 )

\begin{tabular}{|c|c|c|c|c|c|c|c|c|c|}
\hline \multirow[b]{3}{*}{ Region } & \multirow{3}{*}{$\begin{array}{l}\mathrm{PPT}^{1} \\
(\mathrm{~cm})\end{array}$} & \multicolumn{4}{|c|}{ Calves } & \multicolumn{4}{|c|}{ Cows } \\
\hline & & \multirow{2}{*}{$\begin{array}{l}\text { Mortality } \\
\text { change (\%) }\end{array}$} & \multicolumn{2}{|c|}{$\begin{array}{l}95 \% \text { confidence } \\
\text { interval }\end{array}$} & \multirow[b]{2}{*}{$P$-value } & \multirow{2}{*}{$\begin{array}{l}\text { Mortality } \\
\text { change (\%) }\end{array}$} & \multicolumn{2}{|c|}{$\begin{array}{l}95 \% \text { confidence } \\
\text { interval }\end{array}$} & \multirow[b]{2}{*}{$P$-value } \\
\hline & & & Lower & Upper & & & Lower & Upper & \\
\hline Merced $^{2}$ & $>0$ & -2.9 & -21.6 & 20.3 & 0.79 & -3.0 & -21.9 & 20.4 & 0.78 \\
\hline Hanford & $>0$ & -16.9 & -31.9 & 1.2 & 0.07 & 8.4 & -23.0 & 52.8 & 0.64 \\
\hline
\end{tabular}

${ }^{1}$ Controlled for monthly average daily temperature.

${ }^{2} 20$ mo. 
Table 6. Mean (SD) for test-day milk per milking cow (milk, $\mathrm{kg}), 365$-d rolling herd average $(\mathrm{RHA}, \mathrm{kg})$, test-day average $\mathrm{SCC}\left(\times 10^{3} / \mathrm{mL}\right)$, test-day average fat (\%), and herd size over 24 test days for herds in the North Coast $(\mathrm{n}=25)$, North Valley $(\mathrm{n}=34)$, South Valley $(\mathrm{n}=35)$, and Southern California $(\mathrm{n}=18)$

\begin{tabular}{|c|c|c|c|c|}
\hline Variable & North Coast & North Valley & South Valley & S. California \\
\hline RHA (kg) & $9,478(1,912)$ & $9,317(1,672)$ & $10,008(1,064)$ & $9,521(590)$ \\
\hline Test-day SCC $\times 10^{-3} / \mathrm{mL}$ & $223(96)$ & $283(124)$ & $279(111)$ & $376(161)$ \\
\hline Herd size & $370(194)$ & $692(633)$ & $1,560(1,107)$ & $1,260(356)$ \\
\hline
\end{tabular}

(a) Monthly Average Daily Temperature $\left({ }^{\circ} \mathrm{C}\right)$ by Region vs. Testing Month

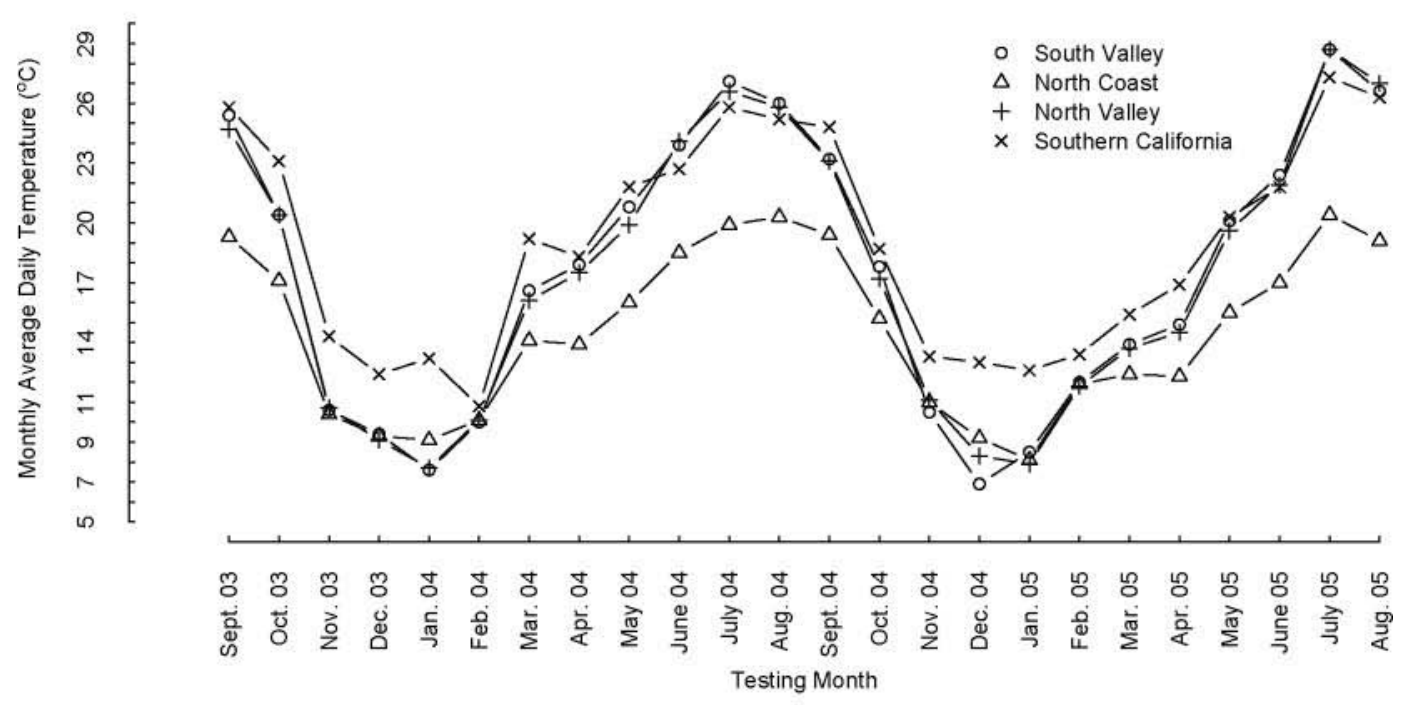

(b) Total Monthly Precipitation (cm) by Region vs. Testing Month

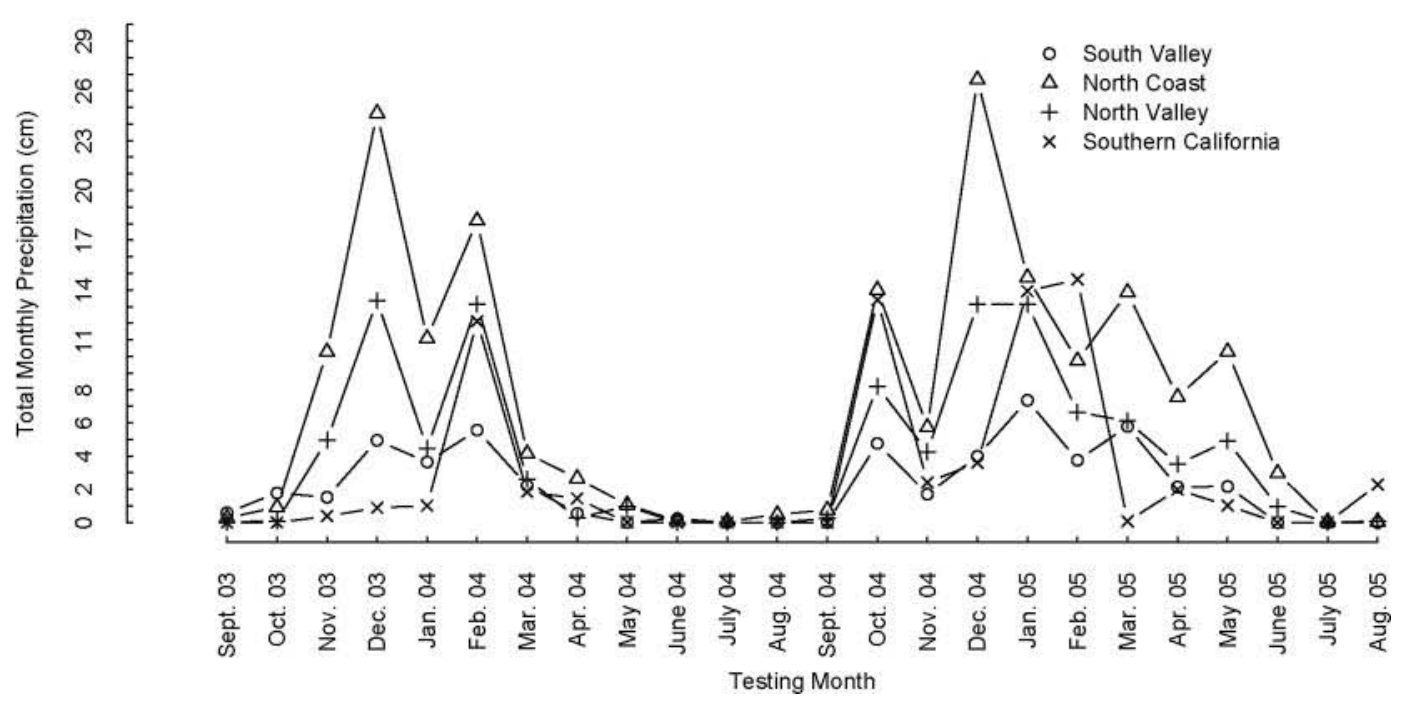

Figure 2. Fluctuation in (a) monthly average daily temperature $\left({ }^{\circ} \mathrm{C}\right)$ and (b) total monthly precipitation (cm) during the 24-mo study period for the 4 geographical locations of California dairies. 
Table 7. Results of generalized estimating equations linear regression of test-day milk per milking cow $(\mathrm{kg})$, fat $(\%)$, and somatic cell count $\left(\mathrm{SCC} \times 10^{-3} / \mathrm{mL}\right)$ on monthly average daily temperature $\left({ }^{\circ} \mathrm{C}\right)$ during a 24 -mo study period for 112 California dairies

\begin{tabular}{lccrrc}
\hline Outcome & $\begin{array}{c}\text { Number }^{1} \\
\text { of dairies }\end{array}$ & $\begin{array}{c}\text { Regression } \\
\text { coefficient }\end{array}$ & \multicolumn{2}{c}{$\begin{array}{c}95 \% \text { confidence } \\
\text { interval }\end{array}$} & $P$-value \\
\hline Milk per cow $(\mathrm{kg})$ & 112 & -0.018 & -0.036 & 0.001 & 0.06 \\
Fat $(\%)$ & 112 & -0.010 & -0.011 & -0.008 & $<0.0001$ \\
$\mathrm{SCC} \times 10^{3} / \mathrm{mL}$ & 112 & -0.652 & -1.487 & 0.183 & 0.13 \\
\hline
\end{tabular}

${ }^{1}$ Each dairy was tested once per month for $24 \mathrm{mo}$; hence, the total number of observations is 2,688.

${ }^{2}$ Expresses the increase in the mean value of the outcome for a $1{ }^{\circ} \mathrm{C}$ increase in monthly average daily temperature.

${ }^{3}$ Adjusted for test day measured as a continuous variable.

California dairies, especially in months with predicted average daily temperatures above $24^{\circ} \mathrm{C}$. These methods may include the utilization of shades, fans, or misting spray on commercial dairies (Armstrong, 1994).

The lower critical temperature for young calves is below $15^{\circ} \mathrm{C}$, at which time the calf must divert energy to maintain its body temperature (Webster, 1992). Again, our model-based results for each rendering region are consistent with proportionately larger increases in mortality in months with average daily temperature below $14^{\circ} \mathrm{C}$ as compared with months with average daily temperature between 14 and $24^{\circ} \mathrm{C}$. In months with expected average monthly temperatures below $14^{\circ} \mathrm{C}$, dairy cattle, especially calves, may benefit from management practices to lessen cold stress such as providing extra energy in the form of feed (National Research Council, 2001) and maintaining a dry environment to decrease the moisture content in the calf's coat (Webster, 1994). Maintaining a dry and warm environment during winter months in California may be difficult under some calf-housing conditions that commonly consist of outside individual pens or hutches (Stull et al., 2004). Additionally, cold stress has been shown to decrease the rate of absorption of colostrum in newborn calves (Olson et al., 1980), thus compromising their immune system and contributing potentially to morbidity and mortality. Recent survey data from the major dairy states in the United States including California showed that although $83 \%$ of heifer calves received colostrum, only $40 \%$ of the heifers received the recommended $3.8 \mathrm{~L}$ (4 quarts) or more of colostrum in the first $24 \mathrm{~h}$ of life (USDA-APHIS-NAHMS, 2007). This failure or partial failure of passive immunity may contribute to morbidity and mortality in dairy calves.

At extremes in temperature, the greater change in mortality of calves compared with cows may be explained by their less developed immune system and consequently greater susceptibility to diseases, in particular of the gastrointestinal (Naylor, 1990) and respiratory tracts (Koterba, 1990). This increase in calf mortality at high and low temperatures (Figure 1) is consistent with another study of calf (less than $36 \mathrm{~d}$ old) mortality-associated weather factors on 16 farms in Tulare County, California, in which cluster analysis showed that high temperatures during the summer and low temperatures during the winter were associated with increased death loss (Martin et al., 1975). These seasonal temperature extremes in the current study were reflected by 2 -fold fluctuations between the months of minimum and maximum mortality for both cows and calves. The processing capacity of the rendering companies should allow for such a varying magnitude in their supply to ensure the timely processing of these carcasses.

Table 8. Results of generalized estimating equations linear regression of test-day milk per milking cow $(\mathrm{kg})$ on monthly average daily temperature stratified by housing types for California dairies

\begin{tabular}{|c|c|c|c|c|c|}
\hline Housing type & $\begin{array}{l}\text { Number }^{1} \\
\text { of dairies }\end{array}$ & $\begin{array}{c}\text { Regression } \\
\text { coefficient }\end{array}$ & \multicolumn{2}{|c|}{$\begin{array}{l}95 \% \text { confidence } \\
\text { interval }\end{array}$} & $P$-value \\
\hline Inside & 32 & -0.009 & -0.038 & 0.020 & 0.56 \\
\hline Outside & 39 & -0.005 & -0.041 & 0.032 & 0.81 \\
\hline Combination $^{4}$ & 41 & -0.035 & -0.063 & -0.006 & 0.02 \\
\hline
\end{tabular}


Table 9. Results of generalized estimating equations linear regression of test-day milk per milking cow $(\mathrm{kg})$ on monthly average daily temperature stratified by geographic location for California dairies

\begin{tabular}{|c|c|c|c|c|c|}
\hline Geographic location & $\begin{array}{l}\text { Number }^{1} \\
\text { of dairies }\end{array}$ & $\begin{array}{c}\text { Regression }{ }^{2,3} \\
\text { coefficient }\end{array}$ & \multicolumn{2}{|c|}{$\begin{array}{l}95 \% \text { confidence } \\
\text { interval }\end{array}$} & $P$-value \\
\hline North Coast & 25 & 0.069 & 0.005 & 0.133 & 0.03 \\
\hline North Valley & 34 & -0.016 & -0.047 & 0.014 & 0.29 \\
\hline South Valley & 35 & -0.044 & -0.071 & -0.016 & 0.002 \\
\hline Southern California & 18 & -0.016 & -0.050 & 0.018 & 0.35 \\
\hline
\end{tabular}

${ }^{1}$ Each dairy was tested once per month for $24 \mathrm{mo}$, hence the total number of observations is 2,688

${ }^{2}$ The increase in the mean value of the average milk yield $(\mathrm{kg})$ per cow on test day for a $1^{\circ} \mathrm{C}$ in monthly average daily temperature.

${ }^{3}$ Adjusted for test day measured as a continuous variable.

Across all California herds enrolled in the DHIA program, the average mortality of mature cows during the period of September 2003 to August 2004 was reported at $5.3 \%$ (VerBoort, 2004). In comparison, during the same time period, the average mortality of mature cows varied between rendering regions with the Hanford $(8.1 \%)$ rendering region experiencing greater mortality, whereas mortality of Merced (5.6\%) and Sacramento (2.1\%) rendering regions were comparable with or less than the California average for DHIA herds. The average herd size also varied between rendering regions with larger herd sizes for the counties in the Hanford (817 to 1,326 cows/dairy) and Merced (750 to 2,375 cows/dairy), and smaller herds in the Sacramento (370 to 814 cows/dairy) rendering regions (CDFA, 2006). Whereas management practices, facility designs, and health programs are herd-specific, herd size has previously been cited as a risk factor for morbidity in other production animal species (Gardner et al., 2007). If herd size was positively associated with mortality, that may explain why dairies in the Sacramento rendering region experienced proportionately lower annual mortality both overall and at the extremes of low and high temperatures (Table 3, Figure 1) than dairies in the other 2 regions.

The summer months in California predictably have elevated temperatures with no rainfall, whereas winter months with lower temperatures receive the rainfall
(Figure 2). Our results showed that mortality in the rainy months did not decrease substantially over months without precipitation, with the exception of calf mortality in the Hanford region. These data suggest that for most regions, precipitation had little or no effect on mortality that was independent of temperature (Table $5)$. In the case of the Hanford calves, we speculate that seasonally applied calf management practices commonly utilized in large herds provided health benefits and subsequently decreased monthly mortality during the months of precipitation and cold. The Hanford rendering region also experienced less monthly precipitation as compared with Merced and Sacramento rendering regions, and this may have contributed to the decrease in mortality of Hanford calves during the winter months with precipitation (Table 2).

Whereas mortality negatively affects herd production and profitability, other production characteristics such as milk quality and yield are also affected by climatic changes, and these relationships may be reflected in DHIA test day data. When the analysis was performed stratifying on geographical location of the dairy, the positive association of monthly average daily temperature with test day milk per milking cow on the North Coast and the negative associations of the other 3 locations suggest an interaction between the effects of temperature and geographic location (Table 9). This difference may be due in part to differences in tempera-

Table 10. Results of generalized estimating equations linear regression of test day milk per milking cow $(\mathrm{kg})$, fat $(\%)$, and SCC $\left(\times 10^{3} / \mathrm{mL}\right)$ on total monthly precipitation $(\mathrm{cm})$ during a 24-mo study period for 112 California dairies

\begin{tabular}{lccrrc}
\hline Outcome & $\begin{array}{c}\text { Number } \\
\text { of dairies }\end{array}$ & $\begin{array}{c}\text { Regression } \\
\text { coefficient }^{2,3}\end{array}$ & $\begin{array}{c}95 \% \text { confidence }^{1} \\
\text { interval }\end{array}$ & $P$-value \\
\hline Milk per cow $(\mathrm{kg})$ & 112 & -0.057 & -0.084 & -0.030 & $<0.0001$ \\
Fat $(\%)$ & 112 & 0.004 & 0.002 & 0.007 & 0.002 \\
SCC $\times 10^{3} / \mathrm{mL}$ & 112 & 0.120 & -0.943 & 1.183 & 0.83 \\
\hline
\end{tabular}

${ }^{1}$ Each dairy was tested once per month for $24 \mathrm{mo}$; hence, the total number of observations is 2,688.

${ }^{2}$ Expresses the increase in the mean value of the outcome for a 1-cm increase in total monthly precipitation.

${ }^{3}$ Adjusted for test day and monthly average daily temperatures measured as continuous variables. 
Table 11. Results of generalized estimating equations linear regression of test day milk per milking cow (kg) on total monthly precipitation stratified by housing types for California dairies

\begin{tabular}{|c|c|c|c|c|c|}
\hline \multirow{4}{*}{$\begin{array}{l}\text { Housing type } \\
\text { Inside } \\
\text { Outside } \\
\text { Combination }^{4}\end{array}$} & \multirow{4}{*}{$\begin{array}{c}\begin{array}{c}\text { Number }^{1} \\
\text { of dairies }\end{array} \\
32 \\
39 \\
41\end{array}$} & \multirow{4}{*}{$\begin{array}{c}\begin{array}{c}\text { Regression } \\
\text { coefficient }\end{array} \\
-0.054 \\
-0.083 \\
-0.040\end{array}$} & \multicolumn{2}{|c|}{$\begin{array}{l}95 \% \text { confidence } \\
\text { interval }\end{array}$} & \multirow{2}{*}{$\frac{P \text {-value }}{0.004}$} \\
\hline & & & -0.089 & -0.017 & \\
\hline & & & -0.132 & -0.034 & 0.0009 \\
\hline & & & -0.069 & -0.011 & 0.006 \\
\hline
\end{tabular}

ture range and variation experienced in the different locations. The average monthly daily temperature for the North Coast dairies was consistently lower and its range was narrower during the 24-mo study than the other 3 locations (Figure 1). Consequently dairies in the North Coast rarely experienced temperatures above $24^{\circ} \mathrm{C}$ range (i.e., temperatures in the range in which milk production is negatively associated with ambient temperature).

In contrast to monthly average daily temperature, the effects of monthly precipitation on milk production were more consistent with a negative association observed regardless of geographic location. The fact that housing-specific associations in test day milk per milking cow were stronger for total monthly precipitation than for monthly average daily temperature suggests that housing type is more likely to mitigate the extreme effects of precipitation than temperature. Approximately one-third of the dairies in the study have both inside confinement and outside housing options for cattle, which may be utilized depending on weather conditions. Interestingly, the strongest negative effect of precipitation on test day milk per milking cow was seen in those dairies that house cattle outside without shelter (corral/pasture). This might be an indication of the benefits of providing housing with shelter from precipitation. It has been shown previously that the provision of shelter lessened the effects of winter weather, especially in thinner cows, and that mature dairy cows when exposed to cold, wet conditions spent less time lying down, had elevated cortisol and thyroxine levels, and spent more time in postures that reduced exposure to wind and rain (Tucker et al., 2007). Suitable housing with shelter during rainy weather in California may minimize the decrease in test day milk per milking cow.

The major limitation of the study lies in the fact that monthly average daily temperature and total monthly precipitation are both environmental and summary measures of exposure, which are likely to be different from the exposures of the individual animal. Consequently, caution should be exercised in extrapolating biologic effects at the individual level. Although the models describe the association between bovine (cow and calf) mortality and temperature or precipitation for each of the 3 rendering regions (Table 4), we advise against placing undue attention to the precise mathematical forms of the variables within these models as opposed to the general shape of these relationships (Figure 1). It is likely that bias due to residual confounding remains in our estimates due to lack of information on potential confounders and the summary nature of exposure variables (Greenland, 2001). Notwithstanding these limitations, the results are plausible. The models for bovine mortality may be a useful tool for the individual dairy producers in understanding the dose response relation-

Table 12. Results of generalized estimating equations linear regression of test day milk per milking cow $(\mathrm{kg})$ on total monthly precipitation stratified by geographic location for California dairies

\begin{tabular}{|c|c|c|c|c|c|}
\hline \multirow{5}{*}{$\begin{array}{l}\text { Geographic location } \\
\text { North Coast } \\
\text { North Valley } \\
\text { South Valley } \\
\text { Southern California }\end{array}$} & \multirow{5}{*}{$\begin{array}{c}\text { Number } \\
\text { of dairies } \\
25 \\
34 \\
35 \\
18\end{array}$} & \multirow{5}{*}{$\begin{array}{c}\text { Regression }^{2,3} \\
\text { coefficient }\end{array}$} & \multicolumn{2}{|c|}{$\begin{array}{l}95 \% \text { confidence } \\
\text { interval }\end{array}$} & \multirow{2}{*}{$\frac{P \text {-value }}{0.0006}$} \\
\hline & & & -0.105 & -0.028 & \\
\hline & & & -0.028 & 0.022 & 0.79 \\
\hline & & & -0.134 & -0.032 & 0.001 \\
\hline & & & -0.053 & -0.004 & 0.02 \\
\hline
\end{tabular}


ship between temperature and bovine mortality. This could be particularly useful for understanding not only within which temperature ranges is dairy level mortality likely to be highest (lowest), but also within which temperature ranges are changes in temperature likely to produce substantial changes in dairy level mortality. In a similar manner the information should also be beneficial to regional rendering companies in predicting their supply and processing needs on a monthly level.

\section{CONCLUSIONS}

Results of this study showed that cow and calf mortality displayed similar U-shaped relationships with environmental temperature for all 3 rendering regions. Calf mortality was more sensitive than cow mortality to extremes of temperature regardless of rendering region. It is expected that months with average daily temperatures less than $14^{\circ} \mathrm{C}$ and greater than $24^{\circ} \mathrm{C}$ will show substantial increases in mortality, and management efforts to alleviate heat and cold stress will be beneficial in reducing cow and calf mortality in these months. Although not seeming an important predictor of mortality, precipitation was negatively associated with test day milk per milking cow regardless of geographic location in California, and particularly among dairies utilizing only outside housing lacking shelter, such as corrals, pastures, or both. This suggests that providing suitable housing for lactating dairy cattle can ameliorate a precipitation-associated decrease in test day milk per cow. Overall, an understanding of the relationship between environmental temperature and precipitation to milk production parameters as well as mortality is beneficial in determining where and when to implement heat and cold stress alleviation practices and provide suitable housing for dairy cows in California. This information will also assist regional rendering services in projecting carcass supply and processing needs. Additional research examining the relationship of climate and dairy production parameters may assist in predicting future outcomes on dairy production systems.

\section{REFERENCES}

Agresti, A. 1996. An Introduction to Categorical Data Analysis. 1st. ed. Wiley, New York, NY.

Allison, P. D. 1999. Logistic Regression using the SAS System: Theory and Application. SAS Institute Inc., Cary, NC.

Anderson, K. L., and R. L. Walker. 1988. Sources of Prototheca spp. in a dairy-herd environment. J. Am. Vet. Med. Assoc. 193:553559 .

Armstrong, D., M. Hillman, M. Meyer, S. Smith, S. Stokes, and J. Harner. 1999. Heat stress management in freestall barns in the Western US. http://www.wdmc.org/1999/HeatStress.pdf Accessed Dec. 20, 2007.
Armstrong, D. V. 1994. Symposium - Nutrition and Heat-Stress. HeatStress interaction with shade and cooling. J. Dairy Sci. 77:20442050.

Berman, A. 2005. Estimates of heat stress relief needs for Holstein dairy cows. J. Anim. Sci. 83:1377-1384.

Berman, A., Y. Folman, M. Kaim, M. Mamen, Z. Herz, D. Wolfenson, A. Arieli, and Y. Graber. 1985. Upper critical-temperatures and forced ventilation effects for high-yielding dairy-cows in a subtropical climate. J. Dairy Sci. 68:1488-1495.

Borderas, T. F., B. Pawluczuk, A. M. de Passille, and J. Rushen. 2004. Claw hardness of dairy cows: Relationship to water content and claw lesions. J. Dairy Sci. 87:2085-2093.

CDFA. 2006. California Department of Food and Agriculture Livestock and dairy. http://www.cdfa.ca.gov/files/pdf/card/ ResDir06_LiveStockDairy.pdf Accessed Dec. 20. 2007.

CDFA. 2005. California Department of Food and Agriculture California Dairy Statistics 2005 Annual. http://www.cdfa.ca.gov/ dairy/pdf/annual/2005/stats_2005_year_report.pdf Accessed Jan. 10, 2008.

Curtis, S. E. 1983. Environmental Management in Animal Agriculture. Iowa State University Press, Ames.

Davis, S., K. Costa, and C. Tatum. 1997. Water, water everywhere. West. Dairyman: 12-14.

Dijkman, J. T., and P. R. Lawrence. 1997. The energy expenditure of cattle and buffaloes walking and working in different soil conditions. J. Agric. Sci. 128:95-103.

Fox, D. G., and T. P. Tylutki. 1998. Accounting for the effects of environment on the nutrient requirements of dairy cattle. J. Dairy Sci. 81:3085-3095.

Gardner, I. A., P. Willeberg, and J. Mousing. 2007. Empirical and theoretical evidence for herd size as a risk factor for swine diseases. Anim. Health Res. Rev. 3:43-55.

Greenland, S. 2001. Ecologic versus individual-level sources of bias in ecologic estimates of contextual health effects. Int. J. Epidemiol. 30:1343-1350.

Heuwieser, W., B. A. Tenhagen, M. Tischer, J. Luhr, and H. Blum. 2000. Effect of three programmes for the treatment of endometritis on the reproductive performance of a dairy herd. Vet. Rec. 146:338-341.

Kirk, J. 1997. Precautions for flood-displaced cows. West. Dairyman: $\mathrm{C} 7$.

Kossaibati, M. A., and R. J. Esslemont. 1997. The costs of production diseases in dairy herds in England. Vet. J. 154:41-51.

Koterba, A. M. 1990. Acute and Chronic Asphyxia in the Neonate. Pages 313-315 in Large Animal Internal Medicine. 1st ed. B. P. Smith, ed. C. V. Mosby, St. Louis, MO.

Lewis, G. S. 1997. Uterine health and disorders. J. Dairy Sci. 80:984994.

Loeffler, A., D. H. Lloyd, and A. Holliman. 2004. Identification and treatment of dermatophilosis in a Cumbrian cattle herd. Vet. Rec. 154:635-636.

Martin, S. W., C. W. Schwabe, and C. E. Franti. 1975. Dairy calf mortality-rate - Association of daily meteorological factors and calf mortality. Can. J. Comp. Med. 39:377-388.

National Research Council. 1981. Dairy Cattle. Pages 75-84 in Effect of Environment on Nutrient Requirements of Domestic Animals. National Academy Press, Washington, DC.

National Research Council. 2001. Nutrient Requirements for Dairy Cattle. 7th. ed. National Academic Press, Washington, DC.

Naylor, J. M. 1990. Manifestations of Disease in the Neonate: Diarrhea in neonatal ruminants. Pages 348-363 in Large Animal Internal Medicine. 1st. ed. B. P. Smith, ed. C.V. Mosby, St. Louis, MO.

Olson, D. P., C. J. Papasian, and R. C. Ritter. 1980. Effects of cold stress on neonatal calves. 2. Absorption of colostral immunoglobulins. Can. J. Comp. Med. 44:19-23.

Ray, D. E., T. J. Halbach, and D. V. Armstrong. 1992. Season and lactation number effects on milk-production and reproduction of dairy-cattle in Arizona. J. Dairy Sci. 75:2976-2983.

Royston, P., G. Ambler, and W. Sauerbrei. 1999. The use of fractional polynomials to model continuous risk variables in epidemiology. Int. J. Epidemiol. 28:964-974. 
Schreiner, D. A., and P. L. Ruegg. 2003. Relationship between udder and leg hygiene scores and subclinical mastitis. J. Dairy Sci. $86: 3460-3465$.

Shultz, T. A., and S. R. Morrison. 1987. Manger misting improves dairy cows' appetite. Calif. Agric. 41:12-13.

St-Pierre, N. R., B. Cobanov, and G. Schnitkey. 2003. Economic losses from heat stress by US livestock industries. J. Dairy Sci. 86(E Suppl.):E52-E77.

Stull, C., S. Berry, B. Reed, and M. Payne. 2004. California Dairy Quality Assurance Program (CDQA) - Dairy Welfare Evaluation Guide. http://cdqa.org/ahw/dweg/ Accessed Oct. 2, 2008.

Tucker, C. B., A. R. Rogers, G. A. Verkerk, P. E. Kendall, J. R. Webster, and L. R. Matthews. 2007. Effects of shelter and body condition on the behaviour and physiology of dairy cattle in winter. Appl. Anim. Behav. Sci. 105:1-13.

Twisk, J., and W. de Vente. 2002. Attrition in longitudinal studies: How to deal with missing data. J. Clin. Epidemiol. 55:329-337.

Twisk, J. W. R. 2003. Applied Longitudinal Data Analysis for Epidemiology: A Practical Guide. Cambridge University Press, Cambridge, UK.

Urdaz, J. H., M. W. Overton, D. A. Moore, and J. E. P. Santos. 2006. Technical note: Effects of adding shade and fans to a feedbunk sprinkler system for preparturient cows on health and performance. J. Dairy Sci. 89:2000-2006.

USDA-APHIS-NAHMS. 2007. United States Department of Agriculture Animal and Plant Health Inspection Services - National Animal Health Monitoring System. Dairy 2007, Part I: Reference of dairy cattle health and management practices in the United States, 2007. http://nahms.aphis.usda.gov/dairy/dairy07/Dairy2007_PartI.pdf Accessed Oct. 2, 2007.

van Amstel, S. R., J. K. Shearer, and F. L. Palin. 2004. Moisture content, thickness, and lesions of sole horn associated with thin soles in dairy cattle. J. Dairy Sci. 87:757-763.

VerBoort, B. 2004. Mortality rates of dairy cows based on DHIA records. Calif. Dairy 13:12-13.

Webster, A. J. F. 1992. Problems of feeding and housing: Their diagnosis and control. Pages 293-333 in Livestock Health and Welfare. R. Moss, ed. Longman Scientific and Technical, Harlow, Essex, UK.

Webster, A. J. F. 1994. Comfort and injury. Pages 50-51 in Livestock Housing. C. M. Wathes and D. R. Charles, ed. CAB International, Wallingford, Oxon, UK.

West, J. W. 2003. Effects of heat-stress on production in dairy cattle. J. Dairy Sci. 86:2131-2144. 